DOI: $10.17516 / 1997-1370-0413$

УДК 304.2

\title{
Ideological Phantoms of Civilisation and Culture: Identity and Tolerance
}

\author{
Natalia Yu. Beregovaya and Olga A. Karlova* \\ Siberian Federal University \\ Krasnoyarsk, Russian Federation
}

Received 17.06.2019, received in revised form 26.08.2019, accepted 09.09.2019

\begin{abstract}
The article considers the philosophical aspect of defining the immanence and attribution of the concept of "tolerance" to the culture itself. The subject of the research is especially relevant due to the modern processes that are happening in the global world, and the difference in key methodological positions of modern Russian and Western science on this issue today. The purpose of this study is to clarify the philosophical basis of the existing opposition of societies with traditional ethical cultures (Russia, China) and the 'new-type' poly-state European ethnic community. Based on the analysis of current social processes in Russia and Europe using the comparative historical method, modelling methods and model extrapolation in the field of culture studies, social psychology and political science, the article identifies the main approaches to ethnic and social identity, their cultural and ideological components. The authors prove the hypothesis that culture requires designation of its border with another culture, recognition of this border, which distinguishes and confirms cultural semantics. Denial of this fact is a method of ideological manipulation of the ethno-social consciousness of society in the framework of globalisation processes.
\end{abstract}

Keywords: Sociocultural communications, cultural model of society, cultural tolerance, sociocultural identity, cultural adherence to pluralism.

Research area: theory and history of culture.

Citation: Beregovaya, N.Yu., Karlova, O.A. (2020). Ideological phantoms of civilisation and culture: identity and tolerance. J. Sib. Fed. Univ. Humanit. Soc. Sci., 13(7), 1090-1098. DOI: 10.17516/1997$1370-0413$.

(C) Siberian Federal University. All rights reserved

* Corresponding author E-mail address: O.A.Karlova@yandex.ru, beregovaya@guszn.admkrsk.ru 


\section{Discussion}

In the modern world, the problem of sociocultural communications is becoming urgent in many areas of life. In connection with the migration of refugees from the Middle East and Africa to Europe and the unprecedented total contacts of extremely different types of cultures and ideas about social reality, one of the most popular terms in European social sciences today is 'tolerance' and its modifications (Karpov, 2017). Scientists have been arguing about this concept, hundreds of scientific papers have been written in its favour and dozens of articles criticising it. In this article, we turn to this concept primarily in the philosophical aspect of the definition of its immanence and attribution to the culture itself.

The concept of tolerance today is especially relevant not only due to many contacts of cultures that are extremely distant in their roots, but also due to the practice of open conflicts caused by gaps in the sphere of sociocultural communications. Contacts of people that belong to different social groups demonstrating the contrast of their values with others often lead to conflicts: these outbreaks associated with social stratification of modern society are typical for school and university environment, including our country. Russia has not overcome public indifference to the problems of disabled people yet, which demonstrates the loss of sociocultural communication, similar to the desire to distance oneself from people of a different social status in everyday life, and the failure of potential adoptive parents to adopt children with disabilities.

\section{Methods}

The importance of the sociocultural identity of people in ethnic, religious and social contacts is universally recognised (Smaldino, 2019; Zolfaghari et al., 2016). Any national culture as the cultivation of a certain type of ideals and patterns is aimed at the development of personal sociocultural identity. The cultivation of ideals means the preservation and reproduction of traditions, archetypes, norms and meanings, i. e. everything that constitutes the content of culture in the synthesis of its spiritual and material components. Signs, meanings and ide- als typical for one or another social group can also be inherited through birth and upbringing among the certain kind of sociocultural reality (Shengquan, Ting Kin, 2019). If we understand identity as personality traits that are included in the process of self-determination, then sociocultural identity can contain personality traits included in the process of self-determination in relation to social groups, ethnic issues and national culture. This appears in the process of identification, the very concept of which came from Late Latin identifico (I identify) (Noveishii filosofskii slovar', 1998). We can say that it is identity that makes a specific personality itself. In contrast to this central concept in traditional culture, Western scholars and politicians in the context of a civilisational approach put the category of tolerance in the centre of cultural development, which was called the measure of 'true culture'. Tolerance (from the Latin tolerantia - patience) is most often understood as endurance in relation to someone else's lifestyle, behaviour and feelings, as well as opinions and beliefs (https://en.wiktionary. org/wiki/tolerance). It is historically connected, as modern Western scholars believe, with pluralism conceivable as a kind of complex quality obtained in the course of the historical 'superimposition' of different sociocultural identities in a situation of centuries-old cohabitation of peoples. The beginning of the latter in Europe took place in the $17^{\text {th }}$ century. Now this quality is considered inherent in all modern European nations in their cultural, religious and political views.

\section{Hypothesis}

It should be specified that culture in a philosophical sense always implies the fact of a different culture, a different understanding, a different sociocultural position. However, does this mean that it must be tolerant of an alien understanding and an alien position up to the rejection of its own identity? We believe that this idea developed on civilisational argumentation, contradicts the philosophical foundations of culture itself. Culture requires the designation of its border with another culture (ethnic, social group, even professional, etc.), the design and recognition of this border, which distinguishes 
and confirms cultural semantics. The denial of this fact is a method of ideological manipulation with the ethno-social consciousness of the society.

\section{Models of sociocultural communications}

There are numerous sociocultural communication models in the modern world which are divided according to the nature of cultural semantics. The most relevant are the models of ethno-cultural communication. In Russia, the cultural model contains the multiplicity of national cultures, and over the millennia of experience in their interaction, certain anti-crisis mechanisms have been developed for preserving identical cultural boundaries. It is noteworthy that, unlike the American model of states, the ethno-cultural boundaries in the Russian model are reflected in the federal and municipal structure of the country. In this model, such political and sociocultural vectors coexist as territorial entities of the federation with titular nations, the national majority and the national diasporas of the regions; indigenous peoples; the old-timers and new comers, as well as various kinds of sociocultural strata. The norm of joint social life of different Russian ethnic groups is based on the indisputable fact that the border between ethno-social cultural phenomena exists, is recognised and has a fundamental character, which distinguishes and confirms their semantics. In this border zone, a free and respectful dialogue of all existing national cultures is one of the regulating conditions for the crisis-free development of the society. The constantly maintained 'equilibrium' of such coexistence is the dialectic of the society development based on 'democracy of nations (large national communities)'. This dialectic presupposes well-known turbulence in real public life: small and large conflicts are one of the sources of sociocultural development, they are constantly generated by factors of social stratification and features of religious worldview, and the specifics of everyday customs in a multinational and socially stratified society.

Taking into account that the peoples of Russia have been coexisting for centuries, is it possible to speak of the pluralism of Russian culture as a certain complex quality, rather than the coexistence of different cultural trends? Undoubtedly, the content of this pluralism is revealed in the concept of 'Russian people'; in this content, the unifying cultural communicator, i. e. the national Russian language, the centuries-old history of the hostel, the largest jointly developed and inhabited territories in the country (Siberia and the Far East), a number of socio-political realities, among which a significant role is played by the state ethnocultural policy in different periods of the development of the country.

The concept of tolerance/intolerance in the Russian society is most often used in the analysis of modern sociocultural contacts of the old-timers and new comers, as well as conflicts in adolescent and student environment associated with the demonstration of different social values and behaviour. Therefore, Russia is often criticised for the lack of legislative mechanisms to combat such evil as human trafficking. This risk zone includes mostly young women who seek moving to Europe and America and constantly replenish the ranks of European and Middle Eastern prostitutes. Indeed, these and other conflicts are intrinsically inherent in the cultural model of modern Russia, which has not yet recovered from the crisis of the $1990 \mathrm{~s}$, and is being strangled economically by strict sanctions. However, these conflicts, in their mass and severity, are removed by the anti-crisis mechanisms existing in the Russian culture itself.

On the other hand, in traditionally prosperous Europe, today they are talking about a sociocultural crisis, and not about local conflicts. Why? How did it happen that, according to scientists, the European model of cultural communications, perfect in its tolerance and pluralism, in the situation of refugees coming to Europe from the Middle East and Africa, 'bursts at the seams' causing irritation and active resistance among the indigenous population of Europe? Let us note that long before these events, it was Western Europe that conceptualised pluralism and tolerance as the main features of the common European cultural identity, although European pluralistic complexity is based on the principles of good neighbourliness formed not 
so long ago (less than a century ago), vectors of ethno-cultural influence, which are quite complicated due to endless national-political redistribution. Such factors as common national language of communication have never existed. Under these conditions, it is reasonable to assume that it is the cultivation of cultural differences with Russia that today serves as the main factor in shaping the cultural identity of Europe, whose tolerance and pluralism are described primarily as the antipodes of traditional Russian cultural diversity.

Indeed, according to Western scholars, the European community is different from traditional communities, which maintained their unity through fundamental traditions in culture and religion. Tolerance in the meaning of 'not imposing one's identity' appears as one of the social products of sociocultural pluralism in the era when the monolithic unity of society has disappeared (Olivier et al., 2008). This applies not only to the ethnic aspect: tolerance has become a byword in connection with, for example, the affirmation of morality and social rights of sexual minorities in Europe. In this aspect, the classical formula of tolerance attributed to Volter, "I do not agree with what you say, but I will sacrifice my life defending your right to express your own opinion", today looks like an implemented metaphor, as European people of traditional views and values often have to put up with the propaganda of sexual minorities even in schools among children. Tolerance implemented in this way appears more as an ideological category than a basic cultural one.

There are many publications in which the identity of the concepts of 'tolerance' and 'respect for another culture, its understanding and acceptance' is affirmed, as well as absence of identity of this concept with tolerance for social injustice, with renunciation of one's beliefs or with concession to the beliefs of others. Nevertheless, in the practical implementation of this formula there is so much conflict that this concept, breaking away from realities of everyday life, gradually turns into an ideological print. Let us clarify that the concept of tolerance looks more realistic in political and economic terms: for example, as trusting the political system of society, which is organised on the basis of elections from a number of opponents, or as economic competition, the basic principle of the harmonious development of capitalist society. However, once again this is more political and economic, but not actually cultural sphere.

Let us state that tolerance is a more 'ideological-superstructure' phenomenon than a basic cultural quality and value. The basis for this assertion also lies in the fact that tolerance in relation to another race, nation, confession, social group with its special mode of existence is impossible without a more fundamental factor, i. e. providing conditions for the free and non-violent development of each of these sociocultural phenomena. If society does not ensure this sociocultural equilibrium, then tolerance and its consequences start to be perceived as injustice and oppression, in other words, as a factor contrary to culture and social justice.

In ethnic psychology, identification is a mechanism for the formation and preservation of ethnic identity and its basic phenomenon, which is ethnic identity. It helps to assimilate and translate ethnic norms and values, stereotypes of behaviour, traditions and rites of the people in the course of ethnisation, the influence on the formation of an ethnically determined worldview is formed. Europe, which claims to have a special model of culture based on pluralism and tolerance, constantly declares them to be universal cultural features being a civilisational achievement, which contributed to the very existence of a special political multi-state universum, the European Union.

It is assumed that such a culture should generate a special cultural identity itself - pluralistic and tolerant, among all the citizens, including representatives of traditional cultures of the Middle East and Africa integrating into the European society. Geopolitical programmes of a number of leading European politicians have been based on this principle, though they are criticised today, since a significant number of non-European migrants have shown their unwillingness to culturally integrate (while seeking to nonetheless receive all the political, economic and social benefits of this society). Some confusion among politicians today, in our opinion, is due to the discovery of the fact that internal pluralistic ties 
in the European culture turned out to be far from universal and ubiquitous, and the appeal of Western European peoples to the sources of their original cultural traditions is becoming increasingly widespread. Moreover, it is not only massive, but also aggressive, if we look at the performances of local nationalists and hard-right forces. Taking into account that, for understandable reasons, public emotions about traditional values and ideals in the tolerant European society are not too prominent and social indifference objectively acts as a companion of tolerance, ultranationalism against this background positions itself as bright and emotionally attractive as ever.

Of course, this cannot be attributed to all European countries, but it once again proves the relative dominance of such qualities as pluralism and tolerance in Western culture. American realities are frankly far from the ideology of tolerance: this is evidenced by the demolition of historical monuments, support for the idea of building a wall on the border with Mexico, a campaign of militant feminism and many other less harmless political and cultural events.

The vector of current Western reality shows that assessing tolerance as a sustainable universal quality of the 'new ethnic group is, mildly speaking, premature. The speed and grouping of the ultranational reaction to the violation of the moral social foundations of a 'pluralistic and tolerant society' suggests that tolerance belongs more to civilisational and ideological, political and economic phenomena rather than basic, ethno-sociocultural phenomena.

This is proved by the constant public manipulation of the Western society with the concepts of 'tolerance/intolerance' when it comes to foreign policy regarding the peoples of Syria, Lebanon, Iran, Venezuela, Cuba, Russia and China. Tolerance loses not only its universal cultural quality, but even its simple meaning when it comes to recognising the sociocultural and any other identity of the peoples of those countries that are in the zone of 'economic interest' of Western states and transnational corporations. These examples have long become rhetorical and show that the declared 'tolerance' (tolerance), strictly speaking, is neither a universal phenomenon, nor "respectful observance of the borders of all cultures", since the peoples are clearly not equal in their cultural value and international practice shows quite obviously who is 'more equal'.

Herewith, disrespect for European values, massively manifested by newcomers who do not want to integrate into the European society, appears on the other hand as a logical reflection of the aggressive and thoughtlessly shortsighted policy of the West towards their own countries and peoples. This obvious fact of international politics allows to come to a logical conclusion in the context of the philosophy of culture: it would be more correct to consider tolerance not as a basic cultural phenomenon declared as such in Western science, but as a factor external to basic cultural values, most often ideological, since in practice it is too selectively applied in favour of the 'superstructure' interests of Western politics and economics.

We proceed from the fact that identification of a person who professes cultural tolerance of the Western European model is the same recognition of the similarities and identities between it and representatives of other nations and cultures, other social groups and faiths, as it happens with representatives of traditional cultures. Although at the same time, it is imposed on ideological ideas cultivated in the society, which are based not on basic cultural realities, but political and economic macro-interests of governments and international corporations. For example, human trafficking is a global process with over 120 thousand women and children becoming its victims every year in Eastern and Central Europe alone. For $\$ 19$ billion (according to media estimates, this is the annual turnover of human trafficking), representatives of the most diverse, including Western cultures, forget about the 'human' community that exists between them and their victims from the 'developing' and sometimes from their own countries. In this sense, we can say that European identity does not include tolerance as a basic component, but accepts it as an external civilisation factor, a state rule of life and an ideological norm that should be followed for the sake of one's own peace. 
The identity of a person in most life situations is not only the basis of their social action, but also the most important sociocultural marker. In other words, the acceptance/non-acceptance by a person of other cultural and social phenomena of modern reality is somehow related to the their own sociocultural characteristics, on the one hand, and on the other, with the method of sociocultural identification typical for this person, since the person's identity itself depends on the identification process being its result. Thus, identification forms identity, and stands on it in the subsequent assessment of the world.

What happens when external (mainly ideological and political) factors dominate in sociocultural identification? Let us note that the fundamental root of iden in the concept of 'identification' means that it does not change for a long time (Slovar' inostrannykh slov, 2006). In other words, we are talking about "equality in the main, unchanging", which belongs to a deep cultural layer or a particularly valuable sacral layer of sociocultural reality or myth. In this sense, we can say that identification is determining the conformity of something to an existing standard taken as some constant basis and having certain parameters (https://businessman.ru/new-chto-takoe-identifikaciyaopredelenie-primery.html). Although it is especially important that this standard is precisely the cultural universe, and not ideological PR.

This thesis can be justified, for example, with the model of culture of the Soviet socialist type in terms of its immanence of the cultural mentality of the 'Russian world'. The latter was able to 'get along' with this incarnation to some extent, since they were united by such common qualities as, for example, 'national mission', 'national asceticism', and, on the other hand, typical underestimation of their own national culture and sociocultural achievements. Moreover, the phenomena being compared are by no means identical, since the basis of the "Soviet socialist culture" was primarily formed by the ideological matrix.

Therefore, identification should be understood as a process of discovering and defining what a given thing (society, nation, object, person) is in sociocultural terms and what it is not.
Let us pay attention to an important fact, in our opinion: this is not about a one-time event, but about some essence considered in a sociohistorical retrospective.

In sociocultural terms, a person identifies themselves with other people on the basis of their own values, emotional reactions and mentality. Thus, the personal I as an internal identity to oneself is maintained throughout life and in some cases demonstrates unity with other personalities expressed in the parameters of the space-time continuum, and in other cases difference from them. The peculiarity of the space-time continuum conceivable herewith is that its parameters ensure understanding of the intersubjective emotional-conceptual whole, and the person considers themselves to be its part. This is me and my social group, and my people. Images, norms, ideals and signs cultivated within the boundaries of this continuum, as well as the collective intuition inherent therein, are perceived as something unchanging, and most importantly, they serve a person as a support in the constant 'lawsuit' with the world and are manifested primarily in crisis situations where "belonging to the whole" allows one to survive and not lose themselves (their own identity).

\section{Conclusion}

Any external object gains its meaning for a person in the process of its evaluation and identification. Strange as it may seem, the main thing here is not determining the truth, but sociocultural demarcation, manifestations of sociocultural identity, which results in the most important quality of identification as a process immanently inherent in culture and sociocultural reality. Emotional connection with an object by the type of assimilation is the main quality of identification outlined by Sigmund Freud, who was the first after the mathematician L. Euler to suggest using the term "identification" in social and humanitarian knowledge as the cornerstone of the theory of psychoanalysis. An emotional connection with certain sociocultural patterns embodied in parents, heroes, or other objects of worship, accompanies us throughout our whole life and serves as the reason for the most important so- 
cial action, which is assimilation (https://psychology.academic.ru/748). For our study, it is important that one of the easiest ways to understand another person is to become emotionally close to them. However, an individual's ability to assimilate is related to the factor of his or her self-identification (identity), in which it acquires the quality of intersubjectivity. A person ceases to be an individual only and acts as part of a whole and at the same time as a representative of this whole, being a manifestation of a particular sociocultural identity. It is this emotional 'manifestation of identity' from the standpoint of which a person most often evaluates external objects and processes to which they are sensitive due to the values they profess.

In a tolerant society, the degree of such 'manifestation' and passionarity is significantly lower. Therefore, paradoxically, tolerance does not strengthen the emotionally coloured sociocultural identity, as some researchers believe, but simply replaces it: as a result, social emotionality is replaced by passivity, and even indifference. Therefore, now, when Russia is trying to follow the example of the West in terms of, for example, ensuring the rights of people with disabilities, it is worth remembering that there is a significant difference between well-developed European legislation in this regard and the standard attitude of society towards this problem.

When the cultural 'foe' is recognized from the standpoint of one's own identity, an object or a process are analysed as a sign system: the signs and characteristics of the objects are compared, their affiliation by similarity and difference is clarified, their specific classification is carried out. Every moment of their existence, a person performs sociocultural (as well as natural biological) scanning of the surrounding world. The results of the scanning process through the nerve endings come to the brain where identification takes place, the results of which form the basis of our actions. This identification is an ongoing process for our brain. By the way, public institutions also work according to this scheme: the main task of television, for example, is the selection and evaluation of facts from every- thing that happens in life. Television, like other media working with a mass audience, inevitably creates a semantic myth itself: selecting and simplifying information, identifying the main semantic dominants, emotional colouring of information. The simplest recognition is made on a binary basis (friend/foe; house/forest; good/evil), which has been known since ancient mythological knowledge reflected in folklore. However, even today, this universal principle of recognition and identification, which is immanent in the culture of humanity, is used practically without changes. Modern information wars have relaunched it, with a mythological scale declaring everything ideologically and politically 'different' as universal 'cultural evil'. The ease with which Russia - after a twenty-year break - has been once again declared "the enemy of progressive and tolerant humanity" proves the extreme topicality of the phenomena of identification in modern culture, its types and characteristics. Anyway, what we see today in "tolerant Western media" does not look as implementation of the principles of the UNESCO Declaration (1995), which emphasises that tolerance is a value and a social norm of civil society, which is manifested, inter alia, in the law of all individuals be different, ensuring sustainable harmony between different faiths, political, ethnic and other social groups, respect for the diversity of various world cultures, civilisations and peoples, readiness for understanding and cooperation with them (https://en.wiktionary.org/wiki/tolerance).

Situational assimilation/dissimilation turning into sustainable, formation on this basis of behavioural stereotypes, uncritical thinking, psychological protection from fears and anxieties: all this works to a certain extent to dissimulate the Western personality from itself and the immanent social and cultural group, and in this sense - the destruction of true sociocultural identity, replacing it with civilisational "cultural simulacra". It can be assumed that the confrontation between "civilisational identification" and "cultural identification" can lead to the latter falling into the field of the unconscious and being actualised only in crisis situations, accompanied by strong social emo- 
tions, aggressiveness, loss of control, depression, and anger typical for this state. Against this background, conscious projective identification provoked by the directed ideological influence of state or mass media policy, will fulfill a protective function for the individual: namely, protection by some kind of virtual object inside (for example, the European Union or the "American world"), thereby creating an illusion control over the situation and satisfaction with 'virtual security'.

This rather dangerous phenomenon manifests itself as an identification vector based on recognition of similarity/identity of events or people, but not in the context of sociocultural reality, but in the context of ideological labels and clichés. The ideology of society has a tremendous impact on the personality: this shows the experience of the Soviet Russia, in which even the project of replacing the cosmocentric Orthodox religiosity (the sacral core of Russian-Slavic culture) with another type of religiosity (sociocentric) (Pivovarov, 2003) was implemented. One of the sources for the success of such a replacement was the psychological protective mechanism, in which, at the unconscious level, people ascribed to themselves the qualities and social norms imposed by social ideology and its ideal carriers. Protection in this case was based on a spectrum of factors: from the need for personal survival to individual peace of mind in the presence of certain norms and standards. Until recently, many authors sought to interpret this path of new sociocultural identification as a purely Russian phenomenon (even despite the presence of a number of earlier revolutionary rearrangements in the state-cultural systems of other peoples in history). A critical look at ideological processes in the culture of European countries today shows that sociocultural identification there can be carried out in non-critical forms, giving rise to modern cultural simulacra and giving new experience to mythological semantic constructions. This makes scientific research of the problem of sociocultural identification in its various aspects more relevant than ever (Lepskii et al.,1972).

\section{References}

Berger, P. \& Lukman, T. (1995). Sotsial'noe konstruirovanie real'nosti. Traktat po sotsiologii znaniia [Social construction of reality. Thoughts on the sociology of knowledge]. Moscow. Medium, 323p.

Freud, S. (1998). Totem and taboo [Totem and taboo: a collection of articles]. Moscow. AST-LTD, $448 \mathrm{p}$.

Identification (2019). In Businessman. Available at: https://businessman.ru/new-chto-takoeidentifikaciya-opredelenie-primery.html

Identification (2019). In Academic Dictionaries and Encyclopedias. Available at: https://psychology. academic.ru/748

Identification, Socialisation (2006). In Encyclopedia of Psychology [Concise Encyclopedia of Psychol$o g y] .2^{\text {nd }}$ ed. Edited by Corsini, R.J., Auerbach, A. J. Moscow; Sanct-Peterburg, Piter, 1096 p.

Karpov, A.O. (2017). Dissonance Tolerance as a New Principle of the Cross-cultural Sustainability. In Procedia-Social and Behavioral Sciences, (237), 723-730.

Lepskii, V.E., Lefevr, V.A. \& Shchedrovitskii, P.G. (1972). Refleksivnye protsessy i upravlenie [Reflective processes and management]. Available at: http://www.reflexion.ru

Noveishii filosofskii slovar' (1998). Edited by Gritsanov, A. A. Minsk, Knizhnyi dom, 896 p.

Olivier, J., Thoenig, M. \& Verdier, T. (2008). Globalization and dynamics of cultural identity. In Journal of International Economics, 2 (76), 356-370. $640 \mathrm{p}$.

Pivovarov, D.V. (2003). Dusha $i$ Vera [Soul and Faith]. Orenburg, OOIPKRO,

Shengquan, Ye. \& Ting Kin, Ng. (2019). Value change in response to cultural priming: The role cultural identity and the impact on subjective well-being. In International Journal of Intercultural Relations. (70), 89-103.

Slovar' inostrannykh slov (2006). Komlev, N. G. Moscow, EKSMO, 669 p. 
Smaldino, P. (2019). Social identity and cooperation in cultural evolution. In Behavioral Processes, (161), 108-116.

Tolerance (2019). In Wiktionary, the free dictionary. Available at: https://en.wiktionary.org/wiki/tolerance

Zolfaghari, B., Mollering, G., Clark, T. \& Dietz, G. (2016). How do we adopt multiple cultural identities? A multidimensional operationalization of the sources of culture. In European Management Journal, (34), 102-113.

\title{
Идеологические фантомы цивилизации и культура: идентичность и толерантность
}

\author{
Н.Ю. Береговая, О.А. Карлова \\ Сибирский федеральный университет \\ Российская Федерачия, Красноярск
}

\begin{abstract}
Аннотация. Статья посвящена философскому аспекту определения имманентности и атрибутивности понятия «толерантность», собственно культуре как таковой. Предмет исследования актуализирован как современными процессами в глобальном мире, так и различием ключевых методологических позиций в данной проблематике, на которых держатся сегодня современная российская и западная наука. Цель настоящего исследования - уточнение философских оснований существующего противопоставления обществ с традиционными этическими культурами (Россия, Китай) и полигосударственной европейской этнической общности «нового типа». На материале анализа происходящих в России и Европе общественных процессов с использованием сравнительно-исторического метода, методов моделирования и модельной экстраполяции в области культурологии, социальной психологии и политологии в статье выявляются основные подходы к этнической и социальной идентичности, культурные и идеологические их составляющие. Подтверждена гипотеза о том, что культура требует обозначения своей границы с другой культурой, признания этой границы, различающей и подтверждающей культурную семантику. Отрицание этого факта - прием идеологического манипулирования этносоциальным сознанием общества в рамках глобализационных процессов.
\end{abstract}

Ключевые слова: социокультурные коммуникации, культурная модель общества, культурная толерантность, социокультурная идентичность, идентификация, плюралистичность культуры.

Научная специальность: 24.00.01 - теория и история культуры. 